\title{
Enterprise Value and Intellectual Capital: Study of BSE 500 Firms
}

\author{
Dr. Priti Sharma ${ }^{1}$ \\ ${ }^{1}$ Assistant Professor, Department of Commerce, Maharshi Dayanand University, Rohtak- India \\ Correspondence: Dr. Priti Sharma, Assistant Professor, Department of Commerce, Maharshi Dayanand University, \\ Rohtak- India
}

Received: January 19, 2018

Accepted: February 7, 2018

Online Published: February 12, 2018

doi:10.5430/afr.v7n2p123

URL: https://doi.org/10.5430/afr.v7n2p123

\begin{abstract}
The purpose of this paper is to estimate the intellectual capital coefficient of the firms under study and to study the relationship, if any between intellectual capital and intellectual capital and its constituents. In this empirical paper, analytical research design has been used. Pulic's VAIC (modified) has been used to estimate the intellectual capital of BSE S\&P 500 listed firms from 2007-2016. The data has been collected from CMIE and collected data has been analyzed using Pearson correlation and linear multiple regression analysis using CMIE PROWESS. Findings show that almost all firms under study have a good VAIC score means above 4 and the top VAIC scorer firms were mainly from refinery, metal, cement, steel, tobacco. Correlation analysis and Linear multiple regression analysis show that $\mathrm{M} / \mathrm{B}$ ratio has a significant relationship with VACA, VAHU, Research and Development (Innovation capital) and Advertisement expenses (customer capital). Year-wise results depicts that value of adjusted $\mathrm{R}^{2}$ is increasing, in 2007 it was just .164 and in the year 2016 it is .607 which infers that VAIC's role is improving in measuring the market value of firms under study. Year wise analysis shows that adjusted $\mathrm{R}^{2}$ is improving, so findings may serve as significant input for the firms to use intellectual capital as the main factor for improving the market value of firms. This paper will definitely contribute to the existing literature.
\end{abstract}

Keywords: intellectual capital, vaic ${ }^{\text {tm }}, \mathrm{m} / \mathrm{b}$ ratio, BSE S\&P 500 firms

Paper type: Research paper

\section{Introduction}

With the advent of information era the base for business has shifted from financial assets to non-financial assets or tangible to intangible assets. Therefore, companies are focussing more on intangible or intellectual capital in order to sustain their position in national and international market. No doubt, tangibles too plays a significant role, but in today's era, the contribution of tangibles is less significant than the intangibles or intellectual capital. Bontis et al, (1999) and Cezair (2008) in their studies said that the intangibles are actually subject to increasing returns, and traditional resources or tangible resources are subject to decreasing returns, it infers that intangibles are the real value drivers of the business firm.

In the words of Sullivan (2000), "Intellectual capital has the ability to leverage the profitability of the firm". Brenan and Connel (2000) point out that Intellectual capital contributes substantially in the discrepancy between book and market value in addition physical and financial assets. Therefore, there is a dire need to explore statistically significant role of intellectual capital in market value as well as in the financial performance of the firm. This contributes not only in literature review, but also of great relevance to the business firm. By knowing the true worth of their firm's intellectual capital, they can pay all due attention to the intangibles or intellectual capital in order to enhance their market value as well as their financial performance.

Several studies have already been conducted for investigating the significant role of Intellectual capital in market value and financial performance at international level and few at in India too. In Indian context, researcher has explored the role of Intellectual capital in market value and financial performance in mainly pharmaceutical and banking sector only. This paper is divided into four sections, in first section consists of definitions of intellectual capital and description of the VAIC model, in second section review of literature pertaining to the intellectual capital and Market value of firms, research gap and objectives, the third section is about the methodology used in the study and analysis (including results), and fourth sections is about conclusions with managerial implications of the present study. 


\subsection{Definition of Intellectual Capital}

The term 'intellectual capital' was first used in a publication by John Kenneth Galbraith in 1969. His concept of the term incorporated a degree of 'intellectual action' rather than 'intellect as pure intellect'. The implication of the view presented by him was that the intellectual capital was more likely to be a dynamic rather than a static form of capital (Edvinsson and Sullivan, 1996: S.358)". As per Business Dictionary, (2006) "Intellectual Capital is the knowledge that can be exploited for some money-making or other useful purpose". Thomas Steward (2001) defined IC as "Intellectual capital is the sum of everything everybody in a company knows that gives it a competitive edge".

\subsection{Value Added Intellectual Coefficient ${ }^{\text {tm }}$ (VAIC)}

Pulic (2000, 2003 and 2005) has made a quite revolutionary attempt by developing a measure to measure the extent by which a firm creates value by virtue of intellectual capital. According to Pulic, VAIC is the sum of ICE (Intellectual Capital efficiency) and CEE (Capital Employed Efficiency). In which, ICE is the sum of HCE (Human Capital efficiency) and SCE (Structural Capital efficiency), here HCE $=$ VA/HC and SCE $=$ SC/VA.

In which, VA = Output - Input, $\mathrm{HC}=$ Human resources cost, $\mathrm{SC}=$ Difference between VA and HC. CEE (Capital Employed Efficiency) $=$ VA/CE.

This method has been widely used by the researches pertaining to assessing the firm's performance based on intangibles or intellectual capital. Besides, certain limitations of this method as e.g. Andriessen (2004, pp. 368) stated that this method is failing to differentiate between the expenses and assets, Stahle et al. (2011) said that Pulic has taken different aspects of certain components of VAIC with respect to the one available in literature and Chang (2007) suggested an amendment in the existing VAIC method in the form of research and development expenses and intellectual capital as these are the two components which are not there in the Pulic's model. Along with these, Chu et. al. (2011) and Maditinos et. al. (2011) also criticized VAIC model on the grounds that it is not a valid measure firm's intellectual capital.

Besides its limitations, this model has been extensively used, the researcher as this the only reliable measure available to gauge the impact of intellectual capital on the firm's performance. Almost more than 35 studies have used this and found quite significant result pertaining to intellectual capital and firm's financial performance.

In the present study, the modified or amended version has been used the author by adding two components i.e. Research and development expenditure as proxy for structural capital and Advertisement expenditure as proxy for relational capital.

\section{Intellectual Capital and Market Value: Literature Review}

Not much work has been done in the context of intellectual capital and market value. This area is still at evolving stage. Lev and Sougiannis (1999) in their study proved that there exists a relationship between innovative capital and market returns. Further in a study conducted by Pulic (2000b) revealed in their study that there is a significant relationship between VAIC and the firm's market value.

Lev (2001) also proved with the help of his study pertaining to S\&P 500 companies for the period of 1977 to 2001 revealed that market value increased almost six fold because of intellectual capital.

In another study Abdolmohammadi (2005) found that it is effective to employ IC on market value. Tseng and James Goo (2005) also found a positive significant relationship between IC and market value. Chen et. al (2005) too proved that there exists a relationship (positive) between IC and market value with the help of their study. Wang, Jui-Chi. (2008) empirically tested relationship between Intellectual Capital and their study also proved the findings of the previous studies pertaining to positive significant relationship.

In a study, conducted by Pina Puntilo (2009) on Italian banking industry revealed different results and proved that there is negative relationship between market value and IC. In another study in Italy, conducted by Veltri and Silvestri (2011), the findings of their study show a significant relationship between IC and the market value of firms. Pal and Soriya (2012) made an attempt to explore the relationship between value added intellectual coefficient and $\mathrm{M} / \mathrm{B}$ ratio of Textile and pharmaceutical companies in India and found no significant association between the two.

Deep and Narwal (2013) found in their study that value added coefficient pertaining to intellectual capital is having no significant impact on the market value of the companies pertaining to selected firms of the Indian textile sector. Ari barkah djamil et.al (2013) conducted a study on 25 banking firms in Indonesia, which is listed on IDX to check the impact of value added intellectual coefficient on the firms' stock return during the year 2005 to 2009. VAIC methodology is used and also regression model is adopted to investigate the relationship between current and future 
stock returns and IC and its components. The results observed that IC does not impact on the current stock return, but affect the stock return growth. Only HCE is having a significant impact on the stock return.

Kharal et al. (2014) check the impact of "value added intellectual coefficient" on organizational performance of oil and gas sector of Pakistan listed on the Karachi stock exchange during the year 2005 to 2013. The results indicate that "value added intellectual coefficient" has significant impact on M/B ratio. Nuryaman (2015) in his study investigated the "impact of the intellectual capital on the firm's value with the financial performance" pertaining to 93 manufacturing companies which are listed on the Indonesia stock exchange. Findings of study revealed that intellectual capital has significant impact on the dependent variable.

Kamath (2015) checks the relationship between "value added intellectual coefficient" and market value of the BSE S\&P SENSEX listed manufacturing firms and found VAIC has some relationship to the market value of the firms under study. Khan and Raushan (2016) too checked the impact of "value added intellectual coefficient" on firm performance of Indian IT industry. And the results were not significant in this case.

\subsection{Limitations of the existing literature}

Literature pertaining to the "relationship between intellectual capital and market value of a firm" is having mixed of opinion, some studies are showing positive correlation while some are showing negative correlation. For example: In a study by, Puntilo (2009), findings shows negative correlation between market to book value ratio and IC. The study was conducted in the Italian banking sector. Same is the case with Pal and Soriya (2012) and Deep and Narwal (2013), their study also showing no impact of IC on the market value of Indian Textile and pharmaceutical companies. Ari barkah djamil et.al (2013) which was conducted on Indonesian banking sector firms, they found that only HCE has a positive and significant impact on the stock return. Study of Khan and Raushan (2016) also shows no significant relationship but the studies of Lev and Sougiannis (1999), Lev (2001), Abdolmohammadi (2005), Tseng and James Goo (2005), Wang, Jui-Chi. (2008), Veltri and Silvestri (2011), Kharal et al. (2014), Nuryaman (2015), and Kamath (2015) shows a significant positive relationship as well impact of "value added intellectual coefficient" on the market value of the firm/s under the study.

\subsection{Research Objectives}

Since literature review is showing no clear relationship (mixed opinion). Hence, it is necessary to explore it more in order to reach some conclusions. In the light of the above reason, in this study an attempt has been made by the author to investigate empirically the relationship between firm's intellectual capital and market-to-book value ratios and also the extent of the impact of intellectual capital on the market value of firms using BSE (S\&P 500) listed firms by taking two control variables i.e. size of the firm and leverage.

\subsection{Hypothesis}

\section{H1: There is significant positive relationship between intellectual capital and firm market to book value.}

H2: There is significant positive impact of intellectual capital on market to book value.

\section{Methodology}

In this research, empirical and analytical research design was used by the researcher as the research was based upon the methodological and philosophical base of logical positivism. In this study, correlation and multiple regression analysis were applied in order to describe the relationship between Intellectual capital and Market to Book value ratio of the firm's under study.

3.1 Study Population: The target population of this study comprised of all BSE (S\&P 500) listed firms in India between the period of 2007 to 2016.

3.2 Data Source: This study was based on both secondary. Secondary data were used for assessing the functional relationship between Intellectual Capital and Market to book value. Secondary data for the period of 2007 to 2016 was collected from Centre for Monitoring Indian Economy (CMIE) PROWESS. CMIE, is one of the Information company in the World. It was established in 1976, primarily as an independent think tank.

\subsection{Models Used for Analyzing the Relationship:}

$$
\begin{aligned}
& \mathrm{M} / \mathrm{B}_{\mathrm{it}}=\alpha_{0}+\alpha_{1} \mathrm{VAIC}_{\mathrm{it}}+€_{\mathrm{it}} \\
& \mathrm{M} / \mathrm{B}_{\mathrm{it}}=\alpha_{0}+\alpha_{1} \mathrm{VACA}_{\mathrm{it}}+\alpha_{2} \mathrm{VAHU}_{\mathrm{it}}+\alpha_{3} \mathrm{STVA}_{\mathrm{it}}+\epsilon_{\mathrm{it}} \\
& \mathrm{M} / \mathrm{B}_{\mathrm{it}}=\alpha_{0}+\alpha_{1} \mathrm{VACA}_{\mathrm{it}}+\alpha_{2} \mathrm{VAHU}_{\mathrm{it}}+\alpha_{3} \mathrm{STVA}_{\mathrm{it}}+\alpha_{4} \mathrm{RD}_{\mathrm{it}}+\alpha_{5} \mathrm{AD}_{\mathrm{it}}+\epsilon_{\mathrm{it}}
\end{aligned}
$$




\subsection{Definitions and Measures of Variables}

In order to analyze the relationship between Intellectual Capital with Market Value and Financial Performance of the companies under study, commonly used measures applied.

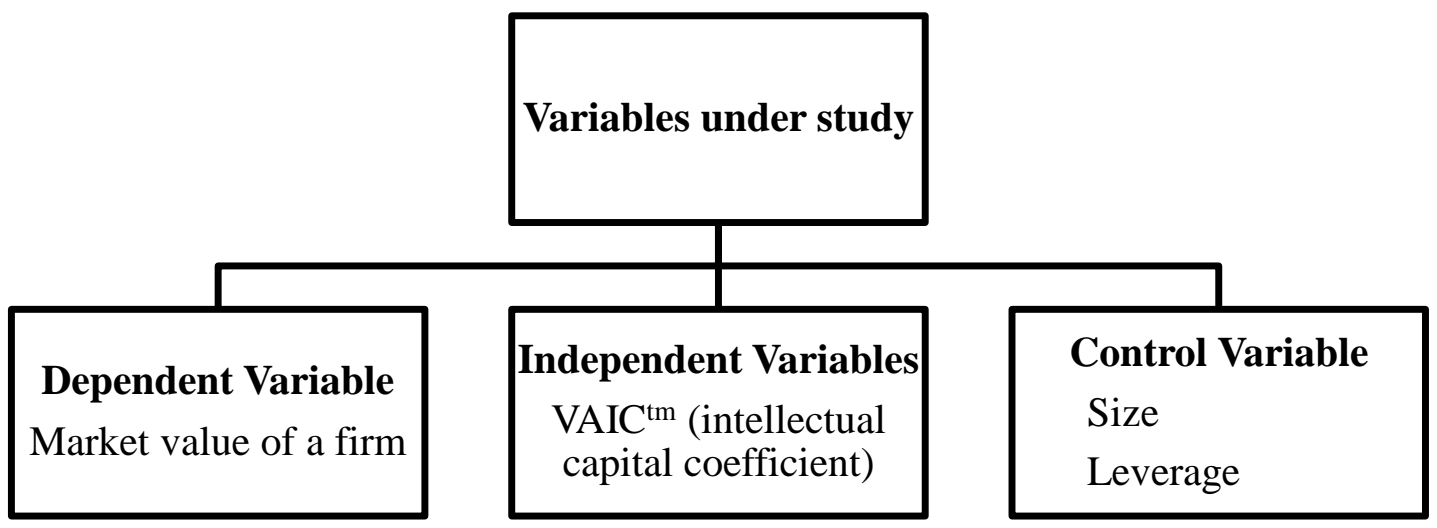

Figure 1. Variables under study

Source: self developed by the author on the basis of literature review

3.4.1 Dependent Variables

Market -to-Book value ratio of common stock

3.4.2 Independent Variables:

The variables of Value Added Intellectual Capital Coefficients (VAIC ${ }^{\mathrm{tm}}$ ) developed by the Pulic were taken as the Independent Variables for this study. VAIC is the combination of VACA, VAHU and STVA.

Where: VACA is the indicator of the VA efficiency of capital employed; VAHU is the indicator of the VA efficiency of human capital; STVA is the indicator of VA of efficiency of structural capital.

$\mathrm{VACA}=\mathrm{VA} \div \mathrm{CE}$

$\mathrm{VAHU}=\mathrm{VA} \div \mathrm{HU}$

$\mathrm{STVA}=\mathrm{SC} \div \mathrm{VA}$

In which, $\mathrm{VA}=\mathrm{S}-\mathrm{B}-\mathrm{D}(\mathrm{S}=$ Sales, $\mathrm{B}=$ Cost of Goods sold and $\mathrm{D}=$ Depreciation $)$,

$\mathrm{CE}=$ Physical Capital + Financial Assets or Total Assets - Intangible Assets,

$\mathrm{HU}=$ Total expenditure on employees

$\mathrm{RD}=\mathrm{R} \& \mathrm{D}$ expenditures $\div$ book value of common stocks

$\mathrm{AD}=$ Advertising expenses $\div$ book value of common stocks

\subsubsection{Control Variables}

Control Variable was used in the study in both the models to control for their effect on firms' performance.

Size (Size of the firm): It is the difference between Total Assets and Total liabilities of the firm.

Market Capitalization: It is the product of Number of outstanding shares and the closing price per share.

Leverage: The amount of debt a firm has in proportion to its equity capital.

\section{Analysis}

The analysis starts with descriptive analysis, which is mainly used to describe the basic nature or the features of the data. Table 1 presents the descriptive statistics for all study variables. 
Table 1. Descriptive Statistics for all study variables

\begin{tabular}{llllll}
\hline & N & Minimum & Maximum & Mean & Std. Deviation \\
\hline VACA & 1458 & -.26 & 3.69 & .6384 & $\mathbf{. 4 2 5 7 4}$ \\
VAHU & 1556 & -8.94 & 85.13 & 10.3180 & $\mathbf{9 . 2 4 3 7 3}$ \\
STVA & 1556 & -1.15 & 13.74 & .8701 & $\mathbf{. 3 4 4 0 3}$ \\
R_D & 1521 & -78.53 & 378.62 & 5.9292 & $\mathbf{2 2 . 1 3 2 5 7}$ \\
ADV & 1554 & -458.06 & 4273.66 & 70.1411 & $\mathbf{2 6 9 . 2 2 7 8 0}$ \\
VAIC & 1458 & -8.05 & 87.90 & 11.6052 & $\mathbf{9 . 3 4 3 7 9}$ \\
MBR & 1461 & -4.18 & 51.04 & 4.2823 & $\mathbf{4 . 8 3 1 5 9}$ \\
Leverage & 1579 & -6.33 & 2415.58 & 3.3642 & $\mathbf{6 2 . 7 8 7 8 0}$ \\
Size & 1579 & 233.60 & 3759651.60 & 122661.1726 & $\mathbf{3 6 2 1 9 4 . 5 2 4 2 1}$ \\
Valid N (listwise) & 1309 & & & & \\
\hline
\end{tabular}

Source: Summarize by the authors

Descriptive statistics include mean, maximum limit, minimum limit, and standard deviation. The mean and standard value of VACA (.6384; sd = .42574), VAHU (10.3180; sd = 9.24373), and STVA (.8701; sd = .34403) infers that the unit under study are more effective in generating value from its human capital rather than physical and structural assets.

Table 2. Correlational Analysis

\begin{tabular}{llllllll}
\hline & VAIC & VACA & VAHU & STVA & R_D & ADV & M/BR \\
\hline VAIC & 1 & & & & & \\
VACA & $.539^{* *}$ & 1 & & & & \\
VAHU & $.999^{* *}$ & $.507^{* *}$ & 1 & & & \\
STVA & $.136^{* *}$ & .025 & $.107^{* *}$ & 1 & & \\
R_D & $-.068^{*}$ & -.052 & $-.070^{* *}$ & -.019 & 1 & \\
ADV & $.128^{* *}$ & $.209^{* *}$ & $.114^{* *}$ & .027 & $.505^{* *}$ & 1 & \\
M/BR & .001 & $.349^{* *}$ & -.016 & .000 & $.127^{* *}$ & $.495^{* *}$ & 1 \\
**. Correlation is significant at the 0.01 level (2-tailed). & & & & \\
*. Correlation is significant at the 0.05 level (2-tailed).
\end{tabular}

The estimated correlation coefficient along with its significance of the dependent (M/B Ratio) and independent variables (VACA, VAHU, STVA, and VAIC) under the study is shown in Table 2. Results show that VAHU has negative correlation with M/B Ratio. Conversely VAIC, VACA and STVA are showing a positive correlation with M/B Ratio which infers that firms' market value is positively associated with intellectual capital and its two constituents. R \& D expenditure (Innovation Capital) and Advertisement expenditure (Relational or Customer Capital) has positive correlation with M/B Ratio. Overall, VAIC is seen to have a positive correlation with M/B Ratio. Ergo, H1 can be accepted.

\subsection{Multiple Linear Regression Analysis}

In order to solve the II objective of the study and to give an in-depth outlook on the relationship between dependent (M/B Ratio) and independent variables (VACA, VAHU, STVA, and VAIC), a multiple linear regression analysis is performed on the models. 
Table 3. Multiple Regression Analysis for Model 1

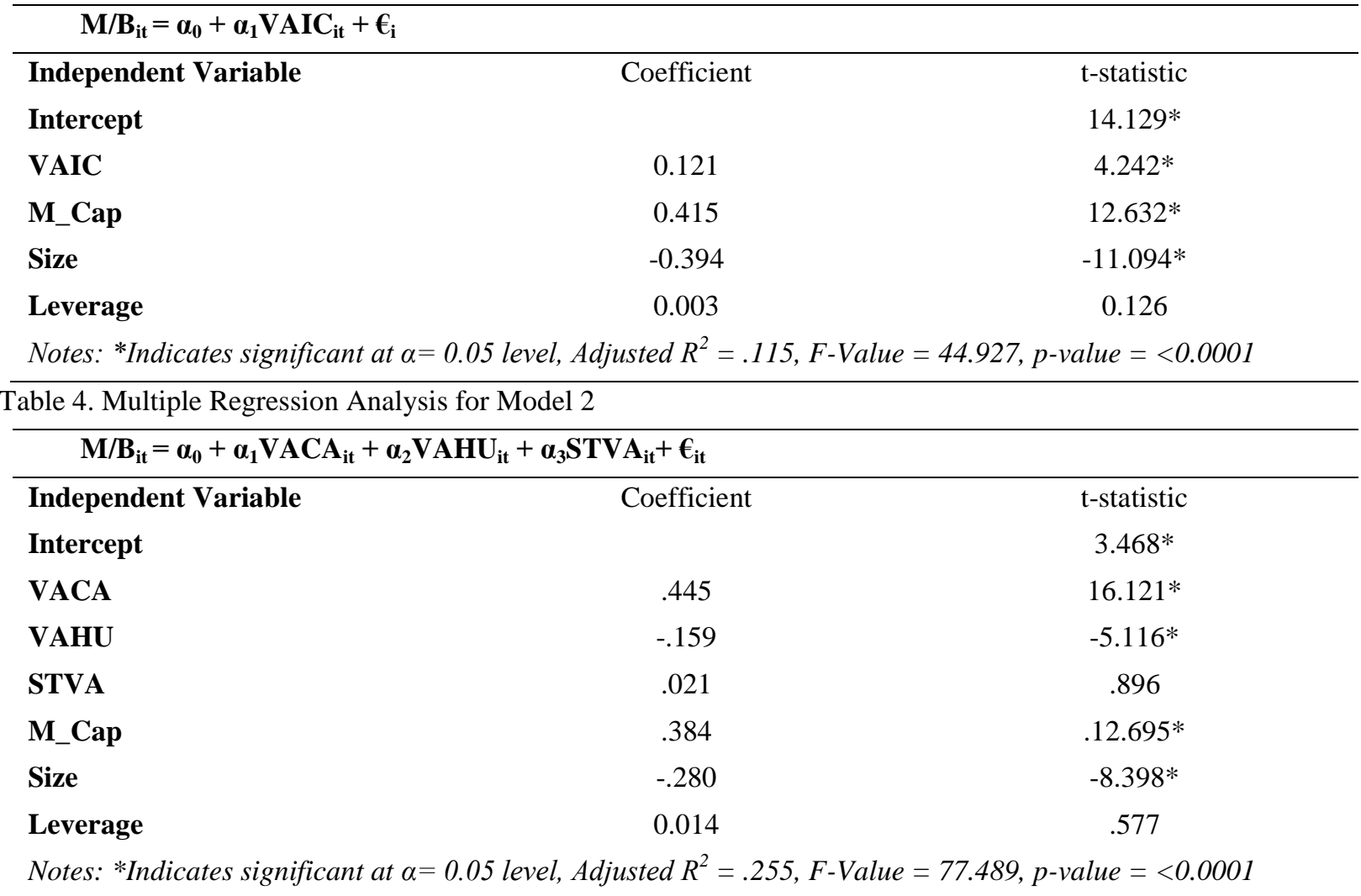

Table 5. Multiple Regression Analysis for Model 3

\begin{tabular}{lcc}
\hline $\mathbf{M} / \mathbf{B}_{\text {it }}=\boldsymbol{\alpha}_{\mathbf{0}}+\boldsymbol{\alpha}_{\mathbf{1}} \mathbf{V A C A}_{\mathrm{it}}+\boldsymbol{\alpha}_{\mathbf{2}} \mathbf{V A H U} \mathrm{U}_{\mathrm{it}}+\boldsymbol{\alpha}_{\mathbf{3}} \mathbf{S T V A}_{\mathbf{i t}}+\boldsymbol{\alpha}_{\mathbf{4}} \mathbf{R D}_{\mathbf{i t}}+\boldsymbol{\alpha}_{\mathbf{5}} \mathbf{A D}_{\mathbf{i t}}+\boldsymbol{\epsilon}_{\mathrm{it}}$ & \\
\hline Independent Variable & Coefficient & $\mathrm{t}$-statistic \\
Intercept & & $5.637^{*}$ \\
VACA & .352 & $13.647^{*}$ \\
VAHU & -.166 & $-5.885^{*}$ \\
STVA & .008 & .399 \\
RD/BV & -.083 & $-3.564^{*}$ \\
AD/BV & .420 & $17.142^{*}$ \\
M_Cap & .341 & $12.008^{*}$ \\
Size & -.307 & $-10.138^{*}$ \\
Leverage & -.014 & -.650
\end{tabular}

Notes: $*$ Indicates significant at $\alpha=0.05$ level, Adjusted $R^{2}=.422, F$-Value $=120.601, p$-value $=<0.0001$

Table 3, 4 and 5 present the results of the three regression models on dependent variable Market to book Value Ratio. Table 3 shows the coefficient of VAIC is significantly positive in the model 1 , and in table 4 coefficients of all the three components of VAIC are positive except VAHU in model 2. The results support H1 and H2 hypotheses except H2-2a for Human Capital efficiency, which infers that firms with greater physical capital and structural capital have a higher M/B ratio and in case human capital efficiency tend to have inverse relation but overall result show that investors place higher value on firms with greater intellectual capital. The adjusted $\mathrm{R}^{2}$ is substantially increased from 0.115 in the model 1 to 0.255 in the model 2 , which depicts that the explanatory power for firm value model 2 is substantially greater than model 2 .

In table 5 result of model 3 show that after controlling STVA, the coefficient of being significantly negative and the adjusted $R^{2}$ is increased from 0.255 in model 2 to 0.422 in the model 3 which infers that model has greater 
explanatory power than the model 2 and model 1 . Result of model 3 shows that the H3-1a hypothesis is not fully supported as the coefficient is not significant in research and development expenses which are used as a proxy for innovative capital. And there is significant supporting evidence of advertisement expenses H3-2a as the coefficient for the same is quite positive which infer that advertisement expenses are a good proxy for relational capital.

The analysis and the empirical findings are not showing any significant positive relationship between firms with any independent variable except VACA and Advertisement expenses which is the substitute for Relationship or customer capital.

However, all the models are showing quite less, but significant adjusted R square which depicts that at least they have significant explaining power. Among control variables it is the Market Cap. which is contributing more to Market value, in some cases, leverage too playing a significant role in explaining the movement in dependent variables.

4.2 Year-Wise Analysis

Table 6. Intellectual capital and M/B ratio

\begin{tabular}{|c|c|c|c|c|c|c|c|c|c|c|}
\hline \multicolumn{11}{|c|}{ Model Summary $^{\mathrm{a}}$} \\
\hline \multirow[t]{2}{*}{ Year } & & $\mathrm{R}$ & $\mathrm{R}$ & Adjusted & $\mathrm{R}$ & Std. Error of the & Change Statistics & & & \\
\hline & & & Square & Square & & Estimate & $\begin{array}{l}\text { R Square } \\
\text { Change }\end{array}$ & $\begin{array}{l}\mathrm{F} \\
\text { Change }\end{array}$ & $\begin{array}{l}\text { Sig. } \\
\text { Change }\end{array}$ & $\mathrm{F}$ \\
\hline \multirow[t]{2}{*}{2007} & 1 & $.270^{\mathrm{b}}$ & .073 & .044 & & 6.85521 & .073 & 2.497 & .064 & \\
\hline & 2 & $.278^{\mathrm{c}}$ & .077 & .038 & & 6.87609 & .004 & .424 & .517 & \\
\hline \multirow[t]{2}{*}{2008} & 1 & $.333^{\mathrm{b}}$ & .111 & .085 & & 7.63593 & .111 & 4.328 & .006 & \\
\hline & 2 & $.399^{\mathrm{c}}$ & .159 & .127 & & 7.46077 & .048 & 5.941 & .017 & \\
\hline \multirow[t]{2}{*}{2009} & 1 & $.409^{\mathrm{d}}$ & .167 & .141 & & 3.08409 & .167 & 6.479 & .000 & \\
\hline & 2 & $.415^{\mathrm{e}}$ & .172 & .137 & & 3.09091 & .005 & .572 & .451 & \\
\hline \multirow[t]{2}{*}{2010} & 1 & $.276^{\mathrm{d}}$ & .076 & .052 & & 2.59803 & .076 & 3.116 & .029 & \\
\hline & 2 & $.278^{\mathrm{e}}$ & .077 & .044 & & 2.60869 & .001 & .078 & .780 & \\
\hline \multirow[t]{2}{*}{2011} & 1 & $.420^{\mathrm{b}}$ & .176 & .155 & & 1.81641 & .176 & 8.347 & .000 & \\
\hline & 2 & $.434^{\mathrm{c}}$ & .189 & .161 & & 1.81060 & .012 & 1.752 & .188 & \\
\hline \multirow[t]{2}{*}{2012} & 1 & $.267^{\mathrm{d}}$ & .071 & .049 & & 1.75776 & .071 & 3.157 & .027 & \\
\hline & 2 & $.302^{\mathrm{e}}$ & .091 & .061 & & 1.74614 & .020 & 2.642 & .107 & \\
\hline \multirow[t]{2}{*}{2013} & 1 & $.247^{\mathrm{d}}$ & .061 & .039 & & 1.92683 & .061 & 2.813 & .042 & \\
\hline & 2 & $.283^{\mathrm{e}}$ & .080 & .052 & & 1.91438 & .019 & 2.696 & .103 & \\
\hline \multirow[t]{2}{*}{2014} & 1 & $.294^{\mathrm{d}}$ & .086 & .064 & & 2.84040 & .086 & 3.878 & .011 & \\
\hline & 2 & $.362^{\mathrm{e}}$ & .131 & .102 & & 2.78185 & .044 & 6.232 & .014 & \\
\hline \multirow[t]{2}{*}{2015} & 1 & $.386^{\mathrm{d}}$ & .149 & .129 & & 4.28967 & .149 & 7.395 & .000 & \\
\hline & 2 & $.410^{\mathrm{e}}$ & .168 & .141 & & 4.25822 & .019 & 2.883 & .092 & \\
\hline \multirow[t]{2}{*}{2016} & 1 & $.365^{\mathrm{d}}$ & .133 & .112 & & 2.40353 & .133 & 6.391 & .000 & \\
\hline & 2 & $.419^{\mathrm{e}}$ & .176 & .149 & & 2.35284 & .043 & 6.445 & .012 & \\
\hline \multicolumn{11}{|c|}{ a. There are no valid cases in one or more split files. Statistics cannot be computed. } \\
\hline \multicolumn{11}{|c|}{ b. Predictors: (Constant), Lev, Size_d, Market_Cap } \\
\hline \multicolumn{11}{|c|}{ c. Predictors: (Constant), Lev, Size_d, Market_Cap, VAIC_coefficient } \\
\hline \multicolumn{11}{|c|}{ d. Predictors: (Constant), Lev, Market_Cap, Size_d } \\
\hline \multicolumn{11}{|c|}{ e. Predictors: (Constant), Lev, Market_Cap, Size_d, VAIC_coefficient } \\
\hline
\end{tabular}


Table 7. Standardized Coefficient value

\begin{tabular}{|c|c|c|c|c|}
\hline \multirow[t]{2}{*}{ Year } & & Standardized Coefficients & \multirow[t]{2}{*}{$\mathbf{t}$} & \multirow[t]{2}{*}{ Sig. } \\
\hline & & Beta & & \\
\hline \multirow[t]{5}{*}{2007} & (Constant) & & -.996 & .322 \\
\hline & Size_d & -.210 & -1.847 & .068 \\
\hline & Market_Cap & .271 & 2.460 & .016 \\
\hline & Lev & .123 & 1.238 & .219 \\
\hline & VAIC_coefficient & .067 & .651 & .517 \\
\hline \multirow[t]{5}{*}{2008} & (Constant) & & -2.431 & .017 \\
\hline & Size_d & -.278 & -2.724 & .008 \\
\hline & Market_Cap & .370 & 3.714 & .000 \\
\hline & Lev & .147 & 1.608 & .111 \\
\hline & VAIC_coefficient & .229 & 2.437 & .017 \\
\hline \multirow[t]{5}{*}{2009} & (Constant) & & -7.000 & .000 \\
\hline & Size_d & -.056 & -.492 & .624 \\
\hline & Market_Cap & .353 & 3.575 & .001 \\
\hline & Lev & .223 & 2.396 & .019 \\
\hline & VAIC_coefficient & -.082 & -.756 & .451 \\
\hline \multirow[t]{5}{*}{2010} & (Constant) & & -.265 & .791 \\
\hline & Size_d & -.184 & -1.718 & .089 \\
\hline & Market_Cap & .278 & 2.797 & .006 \\
\hline & Lev & .047 & .512 & .610 \\
\hline & VAIC_coefficient & .028 & .279 & .780 \\
\hline \multirow[t]{5}{*}{2011} & (Constant) & & 9.769 & .000 \\
\hline & Size_d & -.406 & -4.026 & .000 \\
\hline & Market_Cap & .459 & 4.534 & .000 \\
\hline & Lev & .028 & .333 & .740 \\
\hline & VAIC_coefficient & .111 & 1.324 & .188 \\
\hline \multirow[t]{5}{*}{2012} & (Constant) & & -1.316 & .191 \\
\hline & Size_d & -.096 & -.919 & .360 \\
\hline & Market_Cap & .187 & 1.858 & .066 \\
\hline & Lev & .114 & 1.317 & .190 \\
\hline & VAIC_coefficient & .147 & 1.625 & .107 \\
\hline \multirow[t]{5}{*}{2013} & (Constant) & & -2.932 & .004 \\
\hline & Size_d & -.015 & -.165 & .869 \\
\hline & Market_Cap & .112 & 1.211 & .228 \\
\hline & Lev & .208 & 2.464 & .015 \\
\hline & VAIC_coefficient & .143 & 1.642 & .103 \\
\hline \multirow[t]{5}{*}{2014} & (Constant) & & 1.303 & .195 \\
\hline & Size_d & -.076 & -.849 & .398 \\
\hline & Market_Cap & .258 & 2.920 & .004 \\
\hline & Lev & .102 & 1.204 & .231 \\
\hline & VAIC_coefficient & .216 & 2.496 & .014 \\
\hline \multirow[t]{5}{*}{2015} & (Constant) & & 5.344 & .000 \\
\hline & Size_d & -.285 & -3.278 & .001 \\
\hline & Market_Cap & .379 & 4.430 & .000 \\
\hline & Lev & .004 & .049 & .961 \\
\hline & VAIC_coefficient & .141 & 1.698 & .092 \\
\hline \multirow[t]{5}{*}{2016} & (Constant) & & 4.549 & .000 \\
\hline & Size_d & -.254 & -2.945 & .004 \\
\hline & Market_Cap & .346 & 4.057 & .000 \\
\hline & Lev & -.031 & -.367 & .714 \\
\hline & VAIC_coefficient & .213 & 2.539 & .012 \\
\hline
\end{tabular}

a. There are no valid cases in one or more split files. Statistics cannot be computed. b. Dependent Variable: MB_Ratio 
Table 8. ANNOVA table

\begin{tabular}{|c|c|c|c|c|c|c|}
\hline Year & & Sum of Squares & df & Mean Square & $\mathbf{F}$ & Sig. \\
\hline \multirow[t]{3}{*}{2007} & Regression & 372.071 & 4 & 93.018 & 1.967 & $.106^{\mathrm{d}}$ \\
\hline & Residual & 4444.378 & 94 & 47.281 & & \\
\hline & Total & 4816.450 & 98 & & & \\
\hline \multirow[t]{3}{*}{2008} & Regression & 1087.783 & 4 & 271.946 & 4.886 & $.001^{\mathrm{d}}$ \\
\hline & Residual & 5733.297 & 103 & 55.663 & & \\
\hline & Total & 6821.080 & 107 & & & \\
\hline \multirow[t]{3}{*}{2009} & Regression & 190.332 & 4 & 47.583 & 4.981 & $.001^{\mathrm{f}}$ \\
\hline & Residual & 917.159 & 96 & 9.554 & & \\
\hline & Total & 1107.491 & 100 & & & \\
\hline \multirow{3}{*}{2010} & Regression & 63.625 & 4 & 15.906 & 2.337 & $.060^{f}$ \\
\hline & Residual & 762.189 & 112 & 6.805 & & \\
\hline & Total & 825.814 & 116 & & & \\
\hline \multirow[t]{3}{*}{2011} & Regression & 88.365 & 4 & 22.091 & 6.739 & $.000^{\mathrm{d}}$ \\
\hline & Residual & 380.278 & 116 & 3.278 & & \\
\hline & Total & 468.643 & 120 & & & \\
\hline \multirow[t]{3}{*}{2012} & Regression & 37.315 & 4 & 9.329 & 3.060 & $.019^{f}$ \\
\hline & Residual & 371.979 & 122 & 3.049 & & \\
\hline & Total & 409.294 & 126 & & & \\
\hline \multirow[t]{3}{*}{2013} & Regression & 41.213 & 4 & 10.303 & 2.811 & $.028^{\mathrm{f}}$ \\
\hline & Residual & 472.768 & 129 & 3.665 & & \\
\hline & Total & 513.980 & 133 & & & \\
\hline \multirow[t]{3}{*}{2014} & Regression & 142.087 & 4 & 35.522 & 4.590 & $.002^{\mathrm{f}}$ \\
\hline & Residual & 944.120 & 122 & 7.739 & & \\
\hline & Total & 1086.207 & 126 & & & \\
\hline \multirow[t]{3}{*}{2015} & Regression & 460.535 & 4 & 115.134 & 6.350 & $.000^{\mathrm{f}}$ \\
\hline & Residual & 2284.683 & 126 & 18.132 & & \\
\hline & Total & 2745.218 & 130 & & & \\
\hline \multirow[t]{3}{*}{2016} & Regression & 146.432 & 4 & 36.608 & 6.613 & $.000^{\mathrm{f}}$ \\
\hline & Residual & 686.445 & 124 & 5.536 & & \\
\hline & Total & 832.877 & 128 & & & \\
\hline
\end{tabular}

In the above table No. 7, the P-value for the years 2008 and 2016 are showing significant value. The standardized coefficients for intellectual capital for the above mentioned years are showing significant results.

In year-wise analysis, it is observed that adjusted R Square is showing increasing trend and in every year VACA, Advertisement, M. Cap. and leverage is contributing significantly. In some cases VAHU too is showing significant results. It means firms are gaining awareness towards intellectual capital and taking the required initiatives for making intellectual capital as a significant component.

The partial correlation analysis result is quite positive in case of M/B ratio and VAIC, in which VACA and ADV are having a good positive relationship. The above result depicts mixed of the opinion regarding relationship between intellectual capital and market of firms under study. Mainly VACA and Advertisement expenses are showing significant positive explanatory power as per Indian scenario. VAIC ranking showing quite good results, all most all the sampling units under the study are having more than 5 value added intellectual coefficient. 
In Indian scenario, no doubt, intellectual capital is still at the evolving stage, but sooner or later it will definitely take the pace. There is stern need for the part of the stakeholders mainly the policy makers and corporate decision makers that they will make necessary changes in their internal environment or structure, in their human capital related issues and relational capital in order to increase its impact on market value.

\subsection{Managerial Implications}

The findings of this study are clearly showing significant $R$ Square value in all the three models, and R Square value is improving year by year in year wise analysis, which depicts that intellectual capital coefficient have a significant relationship pertaining to BSE S\&P 500 firms. Most importantly, VACA, ADV and R\&D are contributing significantly in the market to book value ratio.

Now a day's firms is working on the basis of firm specific or industry specific business models. And while developing business models, firms pays all due attention to the key performers or indicators which helps the firm to excel in the market. The findings of this study will definitely helps in framing or developing strategic business model in order to excel in the market. Managers can improve their market share by paying all due attention to the constituents of intellectual capital.

\section{Conclusion}

Findings show that almost all firms under study have a good VAIC score means above 4 and the top VAIC scorer firms were mainly from refinery, metal, cement, steel, tobacco. Correlation analysis and Linear multiple regression analysis show that M/B ratio has a significant relationship with VACA, VAHU, Research and Development (Innovation capital) and Advertisement expenses (customer capital). Year-wise results depicts that value of adjusted $\mathrm{R}^{2}$ is increasing, in 2007 it was just .038 and in the year 2016 it is .149 which infers that VAIC's role is improving in measuring the market value of firms under study.

Year wise analysis shows that adjusted $\mathrm{R}^{2}$ is improving, so findings may serve as significant input for the firms to use intellectual capital as the main factor for improving the market value of firms.

\subsection{Limitations/Future Research, if any}

The paper analyses the relationship of intellectual capital with M/Ratio, it's necessary to check the impact on financial performance. Out of 500 BSE S\&P firms only 160 firm's data have been used which R\&D component in their financial statements. This study analyses the index as a whole, industry wise analysis, comparative analysis should be there. In addition to this, studies on this aspect can also be conducted by taking a qualitative approach in order to support or compare with the results of quantitative studies.

\section{References}

A Dictionary of Business and Management. (2006). Intellectual Capital. Retrieved April 23, 2010 from Encyclopedia.com: http://www.encyclopedia.com/doc/1O18-intellectualcapital.html

Abdolmohammadi, Mohammad J. (2005). Intellectual capital disclosure and market capitalization. Journal of Intellectual Capital, 6(3), 397-416. https://doi.org/10.1108/14691930510611139

Andrissen, D. (2004). Making sense of Intellectual Capital: Designing a method for the valuation of intangibles. Elsevier Butterworth-Heinemann, Burlington, MA.

Bontis N. (1999). Managing organizational knowledge by diagnosing intellectual capital: framing and advancing the state of the field. International, Journal of Technology Management, 18(5/6/7/8), 433-462. https://doi.org/10.1504/IJTM.1999.002780

Cezair. J.A. (2008). Intellectual Capital, Hiding in Plain View. Journal of Performance Management, 13, 29-39

Ming, C. C., Shu, J. C., \& Yuhchang, H. (2005). An empirical investigation of the relationship between IC and Firms' market value and Financial Performance. Journal of Intellectual Capital, 6(2), 159-176. https://doi.org/10.1108/14691930510592771

Deep, R., \& Narwal, K. P. (2014). Intellectual Capital and its Association with Financial Performance: A study of Indian Textile Sector. Int. J. Manag. Bus. Res., 4(1), 43-54 http://ijmbr.srbiau.ac.ir/article_2249_673b29d658b7d0a8aa1a5df0a2b6f2c2.pdf

Edvinsson, L., \& Sullivan, P. (1996). Developing a model of managing intellectual capital. European Journal of Management, 14(4), 356-64. https://doi.org/10.1016/0263-2373(96)00022-9

Galbraith, J. K. (1969). The New Industrial State: Harmondsworth, Penguin. 
Kamath, B. G. (2007). Intellectual capital performance of Indian banking sector. Journal of Intellectual Capital, 8(1), 96-123. https://doi.org/10.1108/14691930710715088

Kamath, B. G. (2008). Intellectual capital and corporate performance in Indian pharmaceutical industry. Journal of Intellectual Capital, 9(4), 684-704. https://doi.org/10.1108/14691930810913221

Kamath, B. G. (2015). Impact of intellectual capital on financial performance and market valuation of firms in India. International Letters of Social and Humanistic Sciences, 48, 107-122. https://doi.org/10.18052/www.scipress.com/ILSHS.48.107

Khan, A. M., \& Raushan, M. A. (2017). An empirical study of the impact of intellectual capital on Indian IT Industry. Available at http://www.otago.ac.nz/pmaa-2017/papers/otago636825.pdf

Kharal, M., Rehman, M. Z., Abrar, M., Khan, M. S., \& Kharal, M. (2014). Intellectual capital and firm performance: An empirical study on the Oil and Gas sector of Pakistan. International Journal of Accounting and Financial Reporting, 4(1), 238-261. https://doi.org/10.5296/ijafr.v4i1.5759

Niamh, B., \& Brenda, C. (2000). Intellectual capital: current issues and policy implications. Journal of Intellectual Capital, 1(3)206-240.

Pal, K., \& Soriya, S. (2012). IC Performance of Indian Pharmaceutical and Textile Industry. Journal of Intellectual Capital, 13(1)120-137. https://doi.org/10.1108/14691931211196240

Puntillo, P. (2009). Intellectual capital and business performance: Evidence from Italian banking industry. Electronic Journal of Corporate Finance, 4(12), 96-115. http://ecsocman.hse.ru/data/687/052/1209/Puntillo_96_115.pdf

Pulic, A. (2000). VAIC- An accounting tool for IC Management. International Journal of Technology Management, 20,702-714. https://doi.org/10.1504/IJTM.2000.002891

Stahle, P., Stahle, S., \& Aho, S. (2011). Value added intellectual coefficient (VAIC): a critical analysis. Journal of Intellectual Capital, 12(04), 531-551. https://doi.org/10.1108/14691931111181715

Stewart, T. A. (2001). The wealth of knowledge: Intellectual capital and the Twenty- first centuary organization, Doubleday, New York, NY.

Sullivan, P. (2000). Value-driven Intellectual Capital: How to convert intangible corporate assets into market value. Wiley.

Tseng, C. Y., \& James Goo, Y. J. (2005). Intellectual capital and corporate value in an emerging economy: empirical study of Taiwanese manufacturers. $R \quad \& \quad D$ Management, $35(2), \quad$ 187-201. https://doi.org/10.1111/j.1467-9310.2005.00382.x

Veltri, S., \& Silvestri, A. (2011). Direct and Indirect effects of human capital on firm value: evidence from Italian companies. Journal of Human Resource Costing and Accounting, 15(3), 232-254. https://doi.org/10.1108/14013381111178596

Wang, J. (2008). Investigating Market Value and Intellectual Capital for S\&P 500. Journal of Intellectual Capital, 9 , 546-563. https://doi.org/10.1108/14691930810913159 